\title{
Coeliac disease: duration of gluten-free diet
}

To the research worker in coeliac disease, interesting questions include: What is the nature of the toxic fraction of gluten? What is the mechanism by which gluten induces abnormalities in the proximal small intestine? But to the child with coeliac disease, and his parents, the most important questions are: For how long must a gluten-free diet be continued? What are the dangers of breaking the diet? Of course, our present inability to answer the coeliac patient's questions with accuracy is a direct result of being unable to answer the questions posed by the research worker.

In the absence of knowledge of the basic aetiology of coeliac disease, working definitions have been proposed that themselves affect management. To an eminent adult gastroenterologist 'coeliac disease is an abnormal jejunal mucosa that responds morphologically to a gluten-free diet'. ${ }^{1}$ This is too general a definition for a paediatrician to use because it would include conditions of transient gluten intolerance that affect young infants. ${ }^{2}$

In 1969, members of the (then) European Society for Paediatric Gastroenterology ${ }^{3}$ proposed that coeliac disease is a permanent condition of gluten intolerance; a gluten-free diet will allow complete recovery of the intestinal mucosal lesion, and gluten reintroduction (a 'challenge') will produce a mucosal relapse. In the ensuing discussions, it was suggested indirectly that mucosal relapse after challenge should occur within 2 years. This definition has been influential in determining the management of coeliac children in Europe. ${ }^{4}$ It introduced the importance of considering the response of the patient to gluten with time. But it may have overstated or oversimplified the facts.

\section{Is coeliac disease permanent?}

No series of coeliac patients has been followed and re-examined throughout life, and therefore permanence has not been proved. There is much evidence to suggest that gluten intolerance is persistent. In several studies in which coeliac children have been re-examined after years on a normal gluten-containing diet, there are an impressive number of clinical lesions and symptoms, particularly anaemia and growth retardation. ${ }^{5-7}$ In one study ${ }^{8}$ the patients had few symptoms, but each one in whom the original diagnosis was supported by intestinal biopsy had an abnormal intestinal mucosa when re-examined.

\section{Do coeliac patients respond uniformly to reintroduction of gluten?}

In series of treated coeliac children who were given relatively large (10-20 g) doses of gluten each day ${ }^{9-10}$ histological relapse was found within 3 to 6 months in $50-77 \%$ of cases. In the studies of Hamilton and McNeill ${ }^{11} 2 \cdot 25 \mathrm{~g}$ gluten daily produced mucosal relapse in only $25 \%$ after 6 months, although over $90 \%$ had relapsed by one year. Taking the series together, there is probably evidence of a doseresponse rate, but individual variation in speed of mucosal response is well recognised. ${ }^{12}$ Delay in mucosal relapse for more than 2 years after restarting gluten is rare $^{13}$ but may occasionally be seen. Egan-Mitchell et al. ${ }^{14}$ recently reported one coeliac child whose mucosa was normal after 28 months of gluten ingestion but which became abnormal after 63-74 months.

These data, together with the studies of 'neglected' coeliac disease described above, all argue that the potential responsiveness of the coeliac mucosa to gluten persists, although the speed and perhaps the extent of the response may vary.

Recent evidence from workers in Paris ${ }^{15}$ suggests that the mucosal responsiveness may vary from time to time. Three French girls, who had early clinical findings entirely compatible with coeliac disease, responded rapidly to a gluten-free diet. Later gluten challenge (physician-planned or patientinspired) produced the typical histological lesions of coeliac disease when the three girls were $4 \frac{1}{2}$ to 10 years old. Gluten was continued for 5-12 years. At age 15-17 years their intestinal mucosas were virtually normal.

Spontaneous clinical improvement of childhood coeliac disease in adolescence was recognised before the advent of a gluten-free diet. ${ }^{16}$ The above cases suggest that mucosal healing can also take place in certain patients although gluten is being ingested. It remains to be seen whether these girls will subsequently show a further histological relapse. If they do not relapse, they will resemble the pattern of temporary intolerance, ${ }^{17}$ but with a very prolonged period of sensitivity. If they do relapse histologically, they will have upset many working 
definitions used at present, and will indicate that latency can exist in the mucosal response to gluten in some cases at some times.

\section{Does the (untreated) mucosal lesion of coeliac disease predispose to malignancy?}

There is a statistically greater incidence of intestinal malignancy, particularly lymphoma and reticulumcell sarcoma, in adults with coeliac disease. ${ }^{18-20}$ Pretreatment for one year with a gluten-free diet does not decrease the incidence of new cases. ${ }^{21}$ However, it is not known whether coeliac patients, on a strict gluten-free diet from childhood, will later have an increased incidence of malignancy.

\section{Summary and conclusions}

In coeliac disease gluten sensitivity is persistent and may well be permanent. Its manifestations, including the severity of the gluten-inducible enteropathy, may vary in individual cases, and perhaps from time to time, but there are no means currently available to predict these responses. The safest advice to our child patients with coeliac disease must be to adhere to a gluten-free diet indefinitely.

The present data on malignancy cannot be applied to a population of childhood coeliacs. If paediatricians choose to use the unknown risk of malignancy as an extra reason for encouraging compliance with a gluten-free diet, they should do so in the knowledge that the case is not proved.

The real clinical need is to maintain or re-establish contact with those coeliac children, often teenagers, who default from the clinic or who insist on returning to a gluten-containing diet. They may have undetected health problems, but even if not, their restudy may have much to teach us about gluten sensitivity. Meanwhile the search continues for the 'cause' of coeliac disease.

\section{References}

1 Booth C C. Discussion. In: McNicholl B, McCarthy C F, Fottrell P F, eds. Perspectives in coeliac disease. Lancaster: MTP Press, 1978: 249.

2 Editorial: Temporary gluten intolerance. Lancet 1976; 2 : 555.

3 Meeuwisse G. Diagnostic criteria in coeliac disease. Acta Paediatr Scand 1970; 59: 461-3.

4 McNeish A S, Harms K K, Rey J, Shmerling D H, Visakorpi $\mathbf{J} \mathbf{K}$, Walker-Smith $\mathbf{J}$ A. The diagnosis of coeliac disease. A commentary on the current practices of members of the European Society for Paediatric Gastroenterology and Nutrition (ESPGAN). Arch Dis Child 1979; 54: 783-6.

5 Mortimer P E, Stewart J S, Norman A P, Booth C C. Follow up study of coeliac disease. $B r$ Med J 1968; iii: 7-9.

6 Sheldon W. Prognosis in early adult life of coeliac disease treated with a gluten-free diet. $B r$ Med J 1969; ii : 401-4.

7 Young W F, Pringle E M. 110 children with coeliac disease 1950-1969. Arch Dis Child 1971; 46: 421-36.

8 McCrae W M, Eastwood M A, Martin M R, Sircus W. Neglected coeliac disease. Lancet 1975; 1: 187-90.

9 Rolles C J, McNeish A S. Standardised approach to gluten challenge in diagnosing childhood coeliac disease. Br Med J 1976; i: 1309-11.

10 Packer S M, Charlton V, Keeling J W, et al. Gluten challenge in treated coeliac disease. Arch Dis Child 1978; 53: 449-55.

11 Hamilton J R, McNeill L K. Childhood celiac disease: response of treated patients to a small uniform daily dose of wheat gluten. J Pediatr 1972; 81: 885-93.

12 Walker-Smith J A, Kilby A, France N E. Reinvestigation of children previously diagnosed as coeliac disease. In: McNicholl B, McCarthy C F, Fottrell P F, eds. Perspectives in coeliac disease. Lancaster: MTP Press, 1978: 267-76.

13 Shmerling D H. Questionnaire of the European Society for Paediatric Gastroenterology and Nutrition on coeliac disease. In: McNicholl B, McCarthy C F, Fottrell P F, eds. Perspectives in coeliac disease. Lancaster: MTP Press, 1978: 245-6.

14 Egan-Mitchell B, Fottrell P F, McNicholl B. Prolonged gluten tolerance in treated coeliac disease. In: McNicholl B, McCarthy C F, Fottrell P F, eds. Perspectives in coeliac disease. I.ancaster: MTP Press, 1978: 251-7.

15 Schmitz J, Jos J, Rey J. Transient mucosal atrophy in confirmed coeliac disease. In: McNicholl B, McCarthy C F, Fottrell P F, eds. Perspectives in coeliac disease. Lancaster: MTP Press, 1978: 259-66.

16 Sheldon W. Celiac disease. Pediatrics 1959; 23: 132-45.

17 McNeish A S, Rolles C J, Arthur L J H. Criteria for diagnosis of temporary gluten intolerance. Arch Dis Child $1976 ; 51$ : 275-8.

18 Gough K R, Read A E, Naish J M. Intestinal reticulosis as a complication of idiopathic steatorrhoea. Gut 1962; 3: 232-9.

19 Harris O D, Cooke W T, Thompson H, Waterhouse J A H. Malignancy in adult celiac disease and idiopathic steatorrhea. Am J Med 1967; 42: 899-912.

20 Stokes P L, Holmes G K T. Malignancy. Clin Gastroenterol 1974; 3: 159-70.

21 Holmes G K T, Cooper B T, Cooke W T. Malignant lymphoma in coeliac disease. In: McNicholl B, McCarthy C F, Fottrell P F, eds. Perspectives in coeliac disease. Lancaster: MTP Press, 1978: 301-3.

A S MCNeISH Department of Child Health, Clinical Sciences Building, Leicester Royal Infirmary, PO Box 65, Leicester LE2 $7 L X$ 